\title{
THE EFFECT OF DESICCATION ON PYRENOID STRUCTURE IN THE OCEANIC LICHEN PARMELIA LAEVIGATA
}

\author{
C. ASCASO ${ }^{\star}$, D. H. BROWN $\ddagger$ and S. RAPSCH ${ }^{\star}$
}

\begin{abstract}
Phycobiont cells of Parmelia laevigata contain chloroplasts with pyrenoids penetrated by a reticulum of tubules. The occurrence and significance of such tubules in algae is discussed. Although these tubules collapsed in desiccated cells, their lumen reappeared on rehydration. However, in such desiccated cells, pyrenoglobuli did not become peripherally located within the pyrenoid, except when damage occurred to the pyrenoid matrix. Rehydration of desiccated cells reduced the number of pyrenoglobuli per pyrenoid.
\end{abstract}

\section{Introduction}

Pyrenoids are proteinaceous bodies found in, or closely associated with, chloroplasts of a variety of algae from all of the major groups. Studies with free-living non-lichen-forming algae have shown that the bulk of the protein in pyrenoids consists of both of the subunits of ribulose-1,5-bisphosphate carboxylase/ oxygenase (RUBISCO, Fraction I protein), the $\mathrm{CO}_{2}$-fixing enzyme of the Calvin cycle, with some other Calvin cycle enzymes. The pyrenoid matrix can be traversed by tubules which may contain membranes derived from the chloroplast thylakoids, although some free-living algal pyrenoids lack such tubules or contain cytoplasmic or nuclear material within the tubules (Griffiths 1980).

The majority of lichen phycobionts contain pyrenoids embedded within their chloroplasts. Generally these are penetrated by short tubules presumed to be lined with thylakoid membranes. The pyrenoid matrix of lichen algae often contains osmiophilic globules, referred to as pyrenoglobuli, which are frequently associated with the surface of the tubules. A number of workers have suggested that these pyrenoglobuli move to the exterior of the pyrenoid on desiccation (Jacobs \& Ahmadjian 1971, Ascaso \& Galvan 1976, Ascaso et al. 1986 ) and that they may represent storage material utilized under conditions of stress (Jacobs \& Ahmadjian 1971, Ahmadjian 1982).

As previously investigated lichens came from habitats subjected to frequent desiccation events, in this study a potentially more desiccation-sensitive species, Parmelia laevigata, was chosen because it is a hyperoceanic species confined to areas of the British Isles experiencing an annual rainfall of at least $127 \mathrm{~cm}$ over 180 rain days (Seaward \& Hitch 1982). In the Dartmoor region it is confined to the upper margins of wooded valleys where it probably regularly receives occult precipitation from low cloud cover. Physiological studies

\footnotetext{
^Instituto de Edafologia y Biologia Vegetal, C.S.I.C., Serrano 115 bis, Madrid 28006, Spain. $\ddagger$ Department of Botany, The University, Bristol BS8 1UG, UK.
} 
(Brown, unpubl.) have confirmed that this species is significantly more sensitive to periods of controlled desiccation in the laboratory. We report here on the ultrastructure of the pyrenoid and changes which occur during such controlled drying experiments.

\section{Material and Methods}

Parmelia laevigata (Sm.) Ach. was collected in November from Holne Woods, near Ashburton, Devon (SX 699702). Material was transported to the laboratory in polythene bags and stored in a moist condition for 2 days on a 12 hour light $\left(250 \mu \mathrm{mol} \mathrm{m} \mathrm{m}^{-2} \mathrm{~s}^{-1}, 20^{\circ} \mathrm{C}\right): 12 \mathrm{~h}$ dark $\left(14^{\circ} \mathrm{C}\right)$ regime.

Excised $1 \mathrm{~cm}$ lobe tips were transferred to transparent containers maintained, at the above light and temperature regime, at (a) $53 \%$ r.h. (10-l volume, over a saturated potassium nitrate solution), (b) $0 \%$ r.h. (5-l volume, over silica gel) and (c) $0 \%$ r.h. (250-ml volume, over silica gel). Conditions (a) and (b) caused slow drying of the material (weight reached equilibrium after $>10 \mathrm{~h}$ ) and condition (c) caused rapid drying (equilibration after $<2.5 \mathrm{~h}$ ). Samples were then either fixed for ultrastructure observations or rehydrated by placing in $10 \mathrm{ml}$ deionized water for $30 \mathrm{~min}$ before fixing, or transferred to a $250-\mathrm{ml}$ container at $100 \%$ r.h. for $24 \mathrm{~h}$, before fixing or placing in deionized water as above. The water contents at different stages of the experiment are shown in Table 1.

TABLE 1. Water content of Parmelia laevigata thalli at different conditions of desiccation and hydration

\begin{tabular}{|c|c|c|c|c|c|}
\hline \multirow[b]{3}{*}{$\begin{array}{l}\text { Desiccation } \\
\text { conditions }\end{array}$} & \multicolumn{5}{|c|}{ Water content ${ }^{\star}$ at different times } \\
\hline & \multirow[b]{2}{*}{$0 \mathrm{~h}$} & \multicolumn{2}{|c|}{24 h dry } & \multicolumn{2}{|c|}{24 h dry +24 h $100 \%$ r.h. } \\
\hline & & Dry & $+0.5 \mathrm{~h} \mathrm{H}_{2} \mathrm{O}$ & Dry & $+0.5 \mathrm{~h} \mathrm{H}_{2} \mathrm{O}$ \\
\hline $0 \%$ r.h. fast $\ddagger$ & $2 \cdot 85$ & 0.01 & 3.50 & $0 \cdot 73$ & $2 \cdot 79$ \\
\hline $0 \%$ r.h. slow & & 0.02 & 1.99 & $0 \cdot 78$ & 1.87 \\
\hline $53 \%$ r.h. slow & & 0.08 & $1 \cdot 80$ & $0 \cdot 78$ & 1.94 \\
\hline
\end{tabular}

$\star$ (Fresh weight - dry weight $) /$ dry weight.

† See Materials and Methods for conditions.

Samples were vacuum infiltrated and fixed in $3.125 \%$ glutaraldehyde in $0.05 \mathrm{M}$ phosphate buffer, $\mathrm{pH} 7 \cdot 1$, for $3 \mathrm{~h}$. Samples were washed in phosphate buffer overnight at $4^{\circ} \mathrm{C}$, post-fixed in $1 \%$ osmium tetroxide, dehydrated in ethanol and embedded in Spurr resin. Specimens were sectioned, stained with lead citrate (Reynolds 1963) and observed in a Philips E.M. 300 electron microscope. Some samples were stained with the OTO technique for lipids (Seligman et al. 1966). Quantitative measurements were made on near-median sections of 15 mature algal cells with a Mop-Videoplan (Kontron) semi-automatic image analyser and statistical tests made using Student's $t$ test.

\section{Results and Discussion}

\section{Pyrenoid structure}

A large, centrally-placed pyrenoid is present in the chloroplast of the trebouxioid algal cells in $P$. laevigata. The pyrenoid matrix is uniform and finely granular, contains numerous osmiophilic pyrenoglobuli and is dissected 


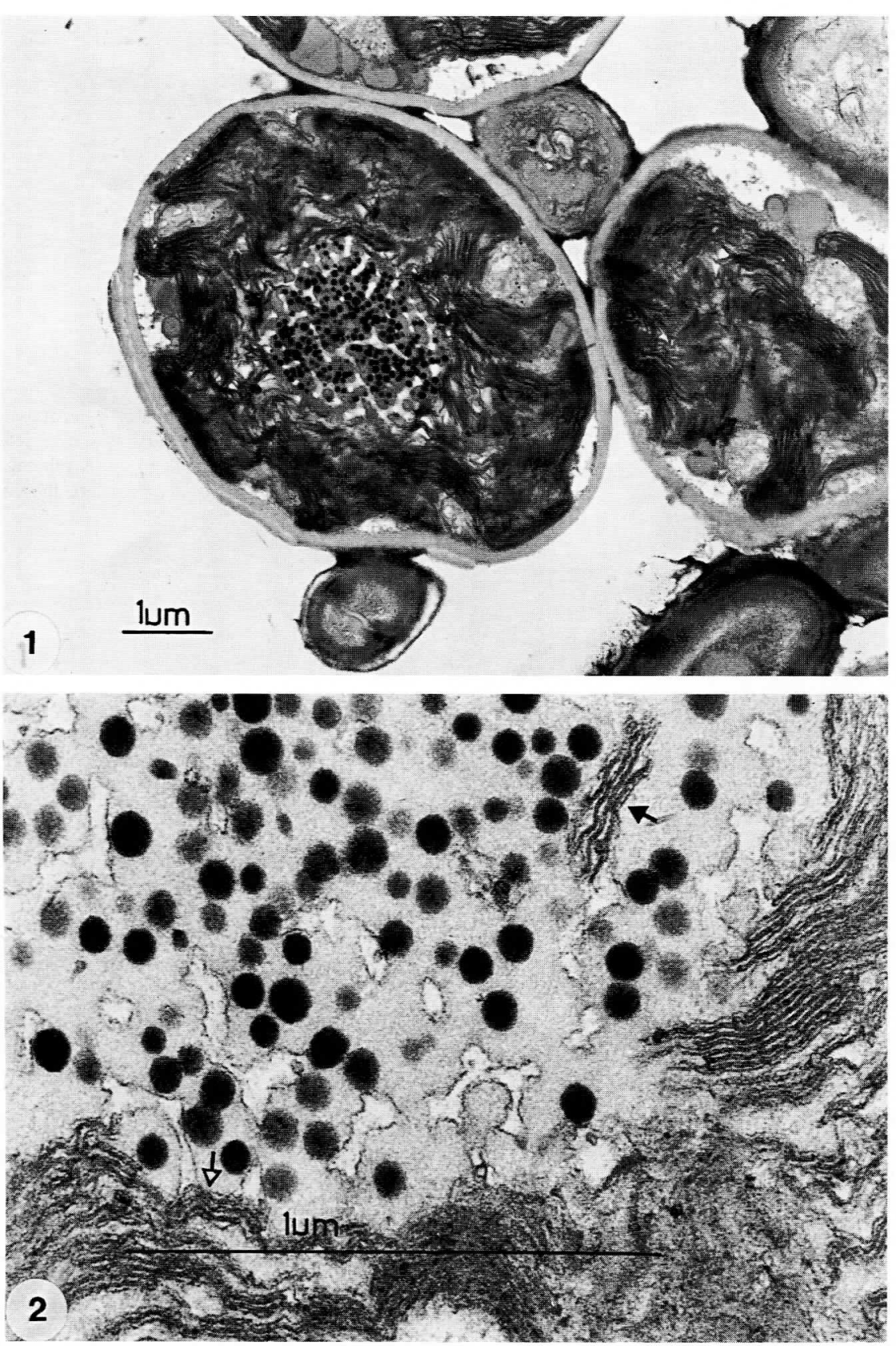

FIGS 1-2. Ultrathin sections of the phycobiont of Parmelia laevigata. FIG. 1. Material stored for $48 \mathrm{~h}$ on moist filter paper on a $12 \mathrm{~h}$ light $\left(250 \mu \mathrm{mol} \mathrm{m}^{-2} \mathrm{~s}^{-1}, 20^{\circ} \mathrm{C}\right): 12 \mathrm{~h}$ dark $\left(14^{\circ} \mathrm{C}\right)$ regime. Fig. 2. Material stored as Fig. 1. before being rapidly dried at $0 \%$ r.h. for $24 \mathrm{~h}$, rehydrated for $24 \mathrm{~h}$ at $100 \%$ r.h. and imbibed in water for $30 \mathrm{~min}$. Open arrow indicates chloroplast thylakoids encircling the pyrenoid, solid arrow indicates thylakoids within a pyrenoid tubule. 

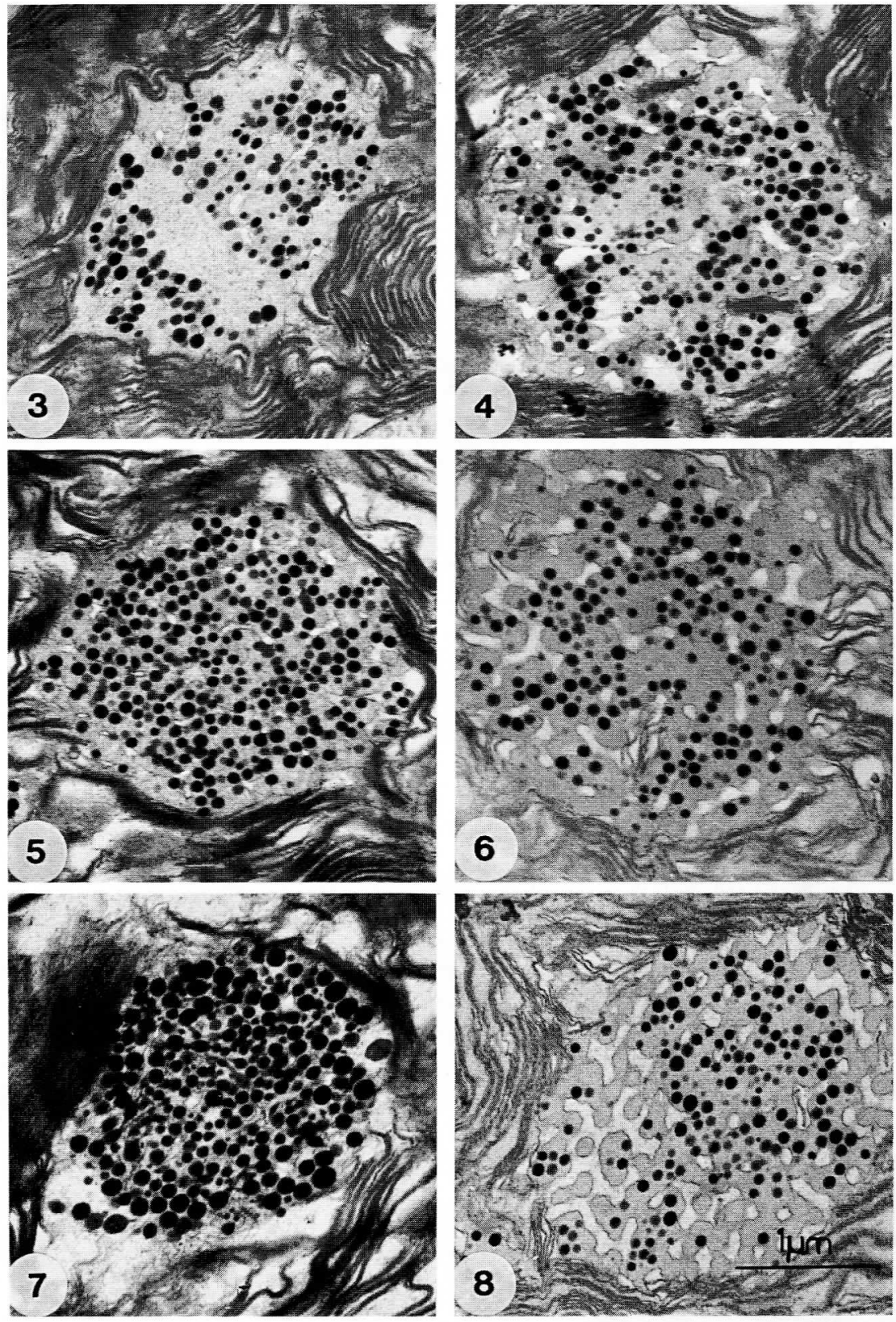

Figs 3-8. Ultrathin sections of pyrenoids from the phycobiont of Parmelia laevigata. All samples were stored moist on a $12 \mathrm{~h}$ light $\left(250 \mu \mathrm{mol} \mathrm{m}^{-2} \mathrm{~s}^{-1}, 20^{\circ} \mathrm{C}\right): 12 \mathrm{~h}$ dark $\left(14^{\circ} \mathrm{C}\right)$ regime before being dried for 24 h. Fig. 3. Material dried slowly at $0 \%$ r.h. Fig. 4 . Material dried slowly at $0 \%$ r.h. and immersed in water for $30 \mathrm{~min}$. FIG. 5 . Material dried rapidly at $0 \%$ r.h. FIG. 6 . Material dried slowly at $0 \%$ r.h. and rehydrated for $24 \mathrm{~h}$ at $100 \%$ r.h. Fig. 7 . Material dried slowly at $53 \%$ r.h. Fig. 8. Material dried slowly at $0 \%$ r.h., rehydrated for $24 \mathrm{~h}$ at $100 \%$ r.h. and immersed in water for $30 \mathrm{~min}$. 
by a reticulate arrangement of tubules (Figs 1-2, $6 \& 8$ ). These tubules can contain groups of thylakoid membranes (Figs $2,4 \& 6$ ) but continuity between the tubule limiting membrane and thylakoid membranes was not clearly established in this species, although it has been demonstrated in some lichens (Fisher \& Lang 1971) and free-living algae (Hobbs 1971, Griffiths 1980). On many occasions the chloroplast thylakoids encircled the pyrenoid, while the tubules penetrated the pyrenoid matrix at right angles to the pyrenoid surface (Fig. 8). The width of the tubules can greatly exceed the internal dimensions of the thylakoids traversing the chloroplast stroma. Tubules with weakly staining contents were observed in cells fixed and stained by the standard method. However, when the OTO technique (Seligman et al. 1966) was used, some tubules had heavily stained contents, implying the presence of lipid-rich material (Ascaso, unpubl.). It is not possible to determine whether this lipid material derived from the degeneration of thylakoid membranes within the

- tubules or the synthesis of specific lipids in tubules.

Previous observations on tubule distribution in pyrenoids of Parmelia sp. have shown them to be simple, cylindrical, unbranched tubes penetrating from the surface or, viewed in cross-section, as circles in the interior of the pyrenoid (Ascaso et al. 1986, Brown et al. 1987a). In thin sections the tubules in $P$. laevigata have a branched, reticulate appearance with occasional circular inclusions of pyrenoid matrix material (Figs 1, $2 \& 8$ ). This form has been reported from the lichens Lecanora muralis (Peveling 1968) and Lecanora radiosa (Galun et al. 1970). Both Lecanora species grow under substantially drier conditions than does $P$. laevigata and, hence, this arrangement of tubules is unlikely to reflect an environmentally-induced condition.

Reticulate pyrenoid tubule arrangements are uncommon in free-living, nonsymbiotic algae, but have been reported in Chlorothrix (Chlorophyceae) by Berger-Perrot \& Thomas (1982). Also, Goodenough \& Levine (1970) reported a stellate arrangement of tubules in the ac-20 mutant of Chlamydomonas reinhardii, which lacks a well-developed pyrenoid matrix when grown mixotrophically.

Our observations on $P$. laevigata are interesting because they show that substantial differences in tubule form, and not just degree of penetration or expansion, can occur within trebouxioid cells. We have no reason to believe that these differences are correlated with other features of the postulated genera Pseudotrebouxia and Trebouxia (Archibald 1975). Griffiths (1970) has commented that 'the detailed structure of the pyrenoid bears no relation with the systematic position of the alga'.

\section{- Effect of thallus water content}

\section{Pyrenoglobuli}

Large numbers of pyrenoglobuli were uniformly distributed within the pyrenoid of all samples of $P$. laevigata (e.g. Figs 4-8). There was no obvious tendency towards a peripheral location of pyrenoglobuli after any of the desiccation treatments. However, some electron micrographs (Fig. 3) showed that, after desiccation, small areas of pyrenoglobuli-free pyrenoid matrix occurred, 
possibly due to the dispersal or degeneration of the pyrenoid matrix (Ascaso \& Galvan 1976, Brown et al. 1987a).

Ascaso et al. (1986) noted in the trebouxioid algae from the substantially more desiccation-resistant Lasallia pustulata that, after short desiccation treatments, the pyrenoglobuli had a more peripheral location in the pyrenoid. The present observations suggest that the similarly brief periods of desiccation (and rehydration) used here were insufficient to induce the redistribution of pyrenoglobuli in $P$. laevigata. Thus pyrenoglobuli do not invariably become located at the periphery of the pyrenoid during desiccation. Further studies with a range of lichens will be required to test whether the failure of pyrenoglobuli to redistribute is correlated with the plants' sensitivity to desiccation or related to the speed of desiccation. In these experiments, although the rate of desiccation was controlled, $P$. laevigata rapidly lost water and achieved equilibrium water contents within $24 \mathrm{~h}$ (Table 1). Lasallia pustulata may be morphologically adapted to reduce the rate of water loss, as has been shown for a number of lichens inhabiting desiccating environments (Snelgar \& Green 1981, Jahns 1984).

The average density of pyrenoglobuli per $\mu \mathrm{m}^{2}$ of pyrenoid cross-sectional area was not significantly altered by any of the desiccation conditions tested, although it was slightly reduced by slow drying (Table 2). Following rehydration, the density of pyrenoglobuli was substantially lessened in material dried slowly (but not rapidly) at $0 \% \mathrm{r}$.h. However, the pyrenoid cross-sectional

TABLE 2. Pyrenoid characteristics of Parmelia laevigata thalli at different conditions of desiccation and hydration

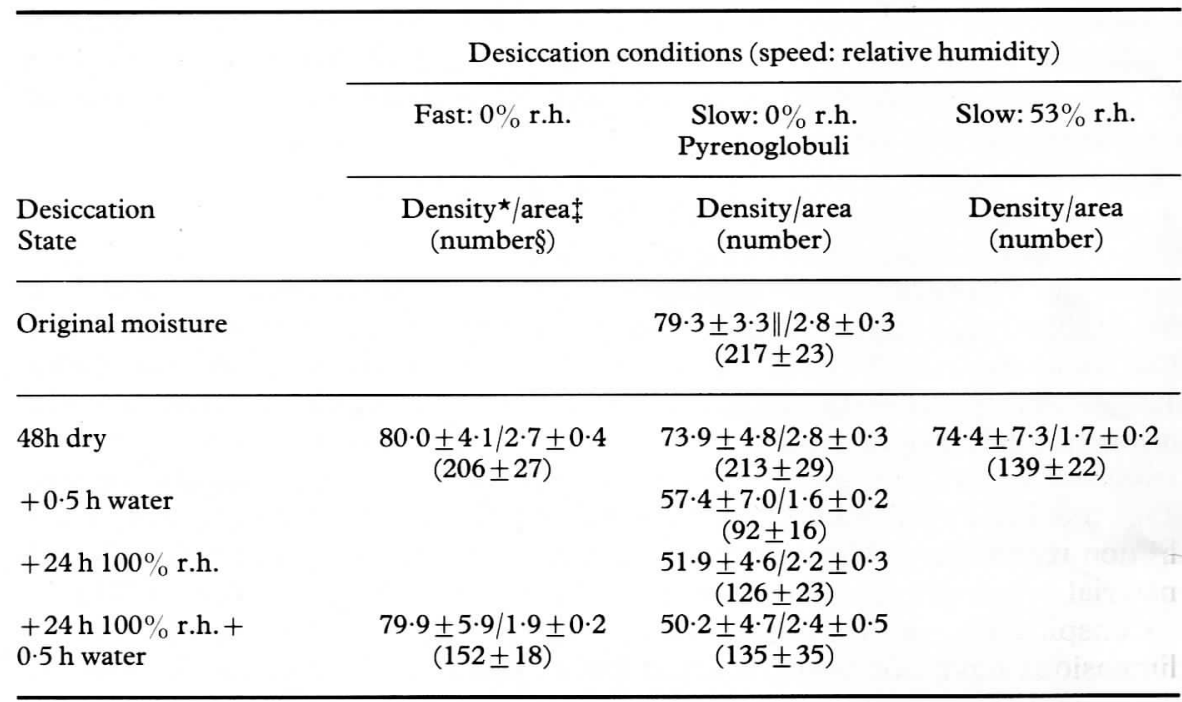

*Average number of pyrenoglobuli per $\mu \mathrm{m}^{2}$ pyrenoid sectional area. $\S$ Average number of pyrenoglobuli per pyrenoid section. $\ddagger$ Average pyrenoid sectional area in $\mu \mathrm{m}^{2}$.

॥Standard error of mean. 
area changed with the desiccation regime, such that, compared to the original hydrated material, it was lower $(P<0.05)$ after slow drying at $53 \%$ r.h. or after placing the material dried slowly at $0 \%$ r.h. in water for $30 \mathrm{~min}$. Although not statistically significant $(P>0 \cdot 05)$, the pyrenoid area possibly recovered somewhat after $100 \%$ r.h. treatment following the slow, but not fast, $0 \%$ r.h. desiccation treatment.

Because of changes occurring in pyrenoid area, the number, rather than density, of pyrenoglobuli per pyrenoid is probably a biologically more relevant feature. Pyrenoglobuli number decreased from the original hydrated state when thalli were slowly dried at $53 \%$ r.h. but not at $0 \%$ r.h. at either speed (Table 2). However, in the samples tested, pyrenoglobuli numbers were lower in rehydrated cells, irrespective of the method of hydration, compared to the desiccated condition. This was most obvious after slow $(P<0.05)$, rather than fast, drying at $0 \%$ r.h.

Loss of pyrenoglobuli may reflect the utilisation of these potentially energyrich lipid stores in metabolism. In these experiments utilization appeared to be linked with (a) possible recovery processes occurring during rehydration and (b) slow drying at a high relative humidity $(53 \%$ compared to $0 \%$ r.h.). Preliminary studies of gas exchange and potassium leakage (Brown, unpubl.) indicated that $P$. laevigata was most severely affected by desiccation at $0 \%$ r.h., with fast drying being particularly damaging. Thus, loss of pyrenoglobuli appears to require a combination of mild stress and the presence of an adequate minimum quantity of cell water for a sufficient period of time. Ascaso et al. (1986) concluded that, in L. pustulata, loss of lipid material had not occurred during desiccation because, while pyrenoglobuli numbers decreased during desiccation, the total area of the pyrenoid which they occupied remained unchanged. Similar measurements were not attempted with $P$. laevigata because a range of staining intensities was observed in the pyrenoglobuli which, it is now considered, could reflect either their position relative to the plane of the section or the utilization of lipid.

\section{Tubules}

The lumen of the pyrenoid tubules was obvious in samples from hydrated thalli (Figs 1-2, 4, 6 \& 8). On desiccation, irrespective of rate of water loss or final water content, the majority of tubules became collapsed and their lumen almost entirely lost (Figs 3, $5 \& 7$ ). Tubule lumens reappear on rehydration of dried material, and this occurs when rehydration is by immediate immersion in deionised water (Fig. 4) or after 24 h rehydration in a $100 \%$ r.h. atmosphere (Figs $6 \& 8$ ). Tubules show the same reticulate profiles following both rehydration techniques. The presence of a few small tubules in some dehydrated material may reflect partial rehydration during fixation (Brown et al. 1987b).

Conspicuous, desiccation-induced, changes in pyrenoid tubule lumen dimensions have not been reported for L. pustulata (Ascaso et al. 1986) or Parmelia sulcata (Brown et al. 1987a). As it is unknown whether tubule form is dictated by the nature of the membranes lining the protein cavity or the composition of the surrounding matrix proteins, the collapse of pyrenoid tubules could be due either to the withdrawal of water from the lumen of the tubule (or 
thylakoid within the tubule) or to a change of configuration of the dehydrated protein structure of the pyrenoid matrix. There is evidence that thylakoid composition is unaltered by containment within the tubule (Holdsworthy 1971), despite reports of decreased chlorophyll content (Gibbs 1962). Some pyrenoids of free-living algae show a crystalline matrix (Griffiths 1980) suggesting ordering of the proteins in the matrix is possible. However, as the pyrenoid matrix is not exclusively RUBISCO (Holdsworthy 1971), it is possible that the different species may possess different degrees of crystallizing capacity under conditions of desiccation. Similarly, variation in pyrenoid protein composition could be used to suggest that the tubule form within the pyrenoid matrix is determined by matrix protein composition and not by any inherent properties of the (thylakoid) membrane system.

We are grateful to Mr F. Pinto for technical assistance. We are pleased to acknowledge that this work was supported by an Acciones Integradas grant from the British Council and Ministerio de Educacion y Ciencia, Spain and grant number PR 84-0169 from the Comission Asesora de Ciencia y Technologia.

\section{REFERENCES}

Ahmadjian, V. (1982) Algal/fungal symbioses. Progress in Phycological Research 1: 179-233.

Archibald, P. A. (1975) Trebouxia de Puymaly (Chlorophyceae, Chlorococcales) and Pseudotrebouxia gen. nov. (Chlorophyceae, Chlorosarcinales). Phycologia 14: 125-137.

Ascaso, C. \& Galvan, J. (1976) The ultrastructure of the symbionts of Rhizocarpon geographicum, Parmelia conspersa and Umbilicaria pustulata growing under dryness conditions. Protoplasma 87: 409-418.

Ascaso, C., Brown, D. H. \& Rapsch, S. (1986) The ultrastructure of the phycobiont of desiccated and hydrated lichens. Lichenologist 18: 37-46.

Berger-Perrot, Y. \& Thomas, J. C. (1982) Etude ultrastructurale comparée du pyrénoide et des parois dans les genres Ulothrix, Chlorothrix et Urospora. Phycologia 21: 355-369.

Brown, D. H., Ascaso, C. \& Rapsch, S. (1987a) Ultrastructural changes in the pyrenoid of the lichen Parmelia sulcata stored under controlled conditions. Protoplasma 136: 136-144.

Brown, D. H., Rapsch, S., Beckett, A. \& Ascaso, C. (1987b) The effect of desiccation on cell shape in the lichen Parmelia sulcata. New Phytologist 105: 295-299.

Fisher, K. A. \& Lang, N. J. (1971) Ultrastructure of the pyrenoid of Trebouxia in Ramalina menziesii Tuck. Fournal of Phycology 7: 25-37.

Galun, M., Paran, N. \& Ben-Shaul, Y. (1970) An ultrastructural study of the fungus alga association in Lecanora radiosa growing under different environmental conditions. Fournal de Microscopie 9: 801-806.

Gibbs, S. P. (1962) The ultrastructure of the pyrenoids of algae, exclusive of the green algae. Fournal of Ultrastructural Research 7: 247-261.

Goodenough, U. W. \& Levine, R. P. (1970) Chloroplast structure and function in $a c-20$, a mutant strain of Chlamydomonas reinhardii. III. Chloroplast ribosomes and membrane organization. fournal of Cell Biology 44: 547-562.

Griffiths, D. J. (1970) The pyrenoid. Botanical Review 36: 29-58.

Griffiths, D. J. (1980) The pyrenoid and its role in algal metabolism. Science Progress, Oxford 66: 537-553.

Hobbs, M. J. (1971) The fine structure of Eudorina illinoiensis (Kofoid) Pascher. Fournal of ${ }^{*}$ Phycology 6: 81-103.

Holdsworthy, R. H. (1971) The isolation and partial characterization of the pyrenoid protein of Eremosphaera viridis. Journal of Cell Biology 51: 499-513.

Jacobs, J. B. \& Ahmadjian, V. (1971) The ultrastructure of lichens. II. Cladonia cristatella: The lichen and its isolated symbionts. Fournal of Phycology 7: 71-82.

Jahns, H. M. (1984) Morphology, reproduction and water relations-a system of morphogenetic interactions in Parmelia saxatilis. Beiheft zur Nova Hedwigia 79: 715-732. 
Peveling, E. (1968) Elektronoptische untersuchungen an flechten. I. Strukturveränderungen der algenzellen von Lecanora muralis (Schreber) Rabenh. (=Placodium saxicolum (Nyl.) sec. Klem.) beim eindringen von pilzhyphen. Zeitschrift für Pflanzenphysiologie 59: 172-183.

Reynolds, S. (1963) The use of lead citrate at high $\mathrm{pH}$ as an electron-opaque stain in electron microscopy. Fournal of Cell Biology 17: 200-211.

Seaward, M. R. D. \& Hitch, C. J. B. (1982) Atlas of the Lichens of the British Isles. Vol. 1. Cambridge: Institute of Terrestrial Ecology.

Seligman, A. M., Wasserkrug, H. L. \& Hanker, J. S. (1966) A new staining method (OTO) for enhancing contrast of lipid-containing membranes and droplets in osmium tetroxide-fixed tissue with osmiophilic thiocarbohydrazine (TCH). Fournal of Cell Biology 30: 424-432.

Snelgar, W. D. \& Green, T. G. A. (1981) Ecologically-linked variation in morphology, acetylene reduction, and water relations in Pseudocyphellaria dissimilis. New Phytologist 87: 403-411. 